\title{
DESIGN, FABRICATION, AND TESTING OF A MOVABLE SOLAR OPERATED SPRAYER FOR FARMING OPERATION
}

\author{
Issa, W.A* \\ Department of Mechanical Engineering, \\ Kwara State University, Malete, Kwara State, Nigeria \\ Abdulmumuni, B, Azeez, R.O, Okpara I.N, Fanifosi, J.O and Ologunye O.B \\ Department of Mechanical Engineering Technology, \\ Federal Polytechnic Ede, Osun State, Nigeria \\ *Corresponding Author
}

\begin{abstract}
Famers do spray seeds, fertilizers, pesticides, herbicides, etc. to protect crops from different insects, pests, diseases and have good harvests. Hand and fuel operated spray pumps are the most common sprayer used in Nigeria. The sprayer causes user fatigue due to excessive bulky and heavy construction, a user can't use it for more than five (5) hours without getting tired, the fuel sprayer is expensive to maintain, emits carbon dioxide and harmful to our environment. In this study, a movable solar operated sprayer for the farming operation was designed and fabricated to overcome these difficulties. The system operates in both direct mode and indirect mode. In the direct mode, the sprayer is operated from the electricity generated by $50 \mathrm{~W}$ solar panel mounted on a movable frame and in the indirect mode it is operated on stored electrical energy in the lead-acid DC battery (12 V, $12 \mathrm{Ah}$ ). Priming diaphragm pump of $10 \mathrm{~W}$ or mini DC reciprocating cycle motor of $5 \mathrm{~W}$ is used to generate the required operating pressure to spray the liquid pesticide formulations. The capacity of the storage tank is 20 liters for uninterrupted operation of 25.1 minutes with the discharge rate of $0.79 \mathrm{~L} / \mathrm{min}$ through the electric flexible mists high-pressure multiple sprayers with four (4) nozzles. Data generated from the theoretical formulae were used to fabricate the system using locally available and durable materials. The sprayer was tested in farmland on two different crops after charging the battery for 3 hours in sunlight. The results obtained were as follows: Power conversion efficiency $20.4 \%$, the time required to charge the battery $2.88 \mathrm{hrs}$, time taken to spray 1 acre of land 2.13hrs, backup time of spray 14.5hrs, application rate $0.04 \mathrm{~L} / \mathrm{m}^{2}$ and operating time of the battery 8hrs. The results obtained show that solar sprayer was effective and will be useful in rural areas where there is no constant power supply. The system is incorporated with an energy bulb and charging kit to light up the farmyard and for the operator to charge his/her phone.
\end{abstract}


Keywords: Power conversion efficiency, Backup time of spray, Discharge \& Application rate.

Cite this Article: Issa, W.A, Abdulmumuni, B, Azeez, R.O, Okpara I.N, Fanifosi, J.O and Ologunye O.B, Design, Fabrication, and Testing of a Movable Solar Operated Sprayer for Farming Operation, International Journal of Mechanical Engineering and Technology, 11(3), 2020, pp. 6-14.

https://iaeme.com/Home/issue/IJMET?Volume=11\&Issue=3

\section{INTRODUCTION}

There is fieldwork normally embark on by farmers in the agricultural sector such as weeding, reaping, sowing, spraying, etc. Out of the which, spraying is the most important operation normally performed by the farmer to protect the cultivated crops from pests, insects, funguses, and diseases for which various insecticides, pesticides, fungicides, and nutrients are sprayed on crops for protection (Krishna M.B, 2017).

The recent concern on how to control plant diseases, insects and weeds for the qualitative yield of agricultural products is increasing rapidly in many developing countries like Nigeria. Crop spraying is employed for many varieties of purposes in the traditional farming system by dipping brushes, leaves or brooms into diluted water added to chemicals in an open container and sprinkling on the required area.

A sprayer is a mechanical device used to spray liquid like herbicides, pesticides, fungicides, and fertilizers to the crops to prevent pests or insects from destroying the crops. Sprayer provides optimum utilization of pesticides or any other chemicals with minimum efforts and less cost. Farmers normally use hand or fuel operated sprayers to perform this task. This traditional spraying method causes user fatigue due to excessive bulky and heavy construction (Arunkumar M., 2015).

In Nigeria farms generally, two types of spray pumps are used for spraying; hand-operated spray pump and fuel operated spray pump, out of which hand-operated spray pumps are most common. The setback of the hand-operated spray pump is that the user cannot use it continuously for more than five (5) to six (6) hours since he/she gets tired after such a long time. Similarly, the fuel operated spray pump requires fuel which is expensive and available in the rural areas. At the same time, it emits carbon dioxide as a pollutant that is harmful to our environment. In such a situation, there should be a need to think about how to move towards some non-conventional energy. Considering it, solar energy would be one of the best solutions (Ahalya M., 2017).

The development in pesticides sprayer brings a revolution in the agriculture/horticulture sector which assists farmers to obtain the maximum agricultural output. A sprayer is used for agriculture spraying, garden spraying, weed, and pest control, liquid fertilizing and plant leaf polishing. There are a lot of advantages derived from sprayers such as easy to operate, maintain and handle. It increases the uniform spread of chemicals, capable of throwing the liquid formulation at the desired level, throwing foggy, light and heavy spray depending on the requirement (Pandurang L., 2015).

There are a lot of difficulties normally faced by Nigerian farmers due to harsh weather and thus affect the spray quality and pattern. It also prevents farmers to harness the benefit of the pesticide application even after investing costs and efforts. The available battery operated sprayers have operational constraints such as choking of a nozzle, poor quality of spray, high human effort, low field capacity, the uncertainty of grid power availability and deep discharge of the battery, etc. It was discovered that about 50\%-80\% of applied pesticide is wasted due to poor spray machinery and improper application methods. During spraying, farmers swing the 
spray nozzle head that results in uneven application of pesticides making the operation less efficient and uneconomical (Rahul V.K, 2018).

In Nigeria, $73 \%$ of the population is directly or indirectly dependent upon the farming produce. Hence Nigeria is now an agricultural producing nation, but still, farmers face numerous problems such as; pest, lack of mechanization, short supply of electricity and existing method (Ergonomically imperfect). To overcome these difficulties, a "movable solar operated sprayer" has been developed. This system can be operated using solar energy, which is converted into electrical energy and stored in a storage battery.

\section{AIM AND OBJECTIVES}

This project aims to design, fabricate and test a movable solar operated sprayer for a farming operation.

The objectives of the project are;

$>$ To design a solar operated sprayer capable of spraying up to 650litres of pesticides and herbicides daily

$>$ To fabricate and test the sprayer on two (2) different crops

$>$ To evaluate the performance of the sprayer

\section{LITERATURE REVIEW}

There is a lot of researchers works done on different types of sprayer such as a high-pressure sprayer, the engine operated sprayer, tractor mounted sprayer, etc.

$>$ (Joshua R., 2010): Developed a power sprayer with the two-stroke petrol engine. The cost of operating the system is quite high and thus solar operated sprayer is suggested as an alternative.

$>$ Rao et. al. (2013): Developed a multiple power supplied fertilizer sprayer that can spray up to 580 liters of pesticide in about 5-6 acre of land when the battery is fully charged.

$>$ Khan (2014): designed a spray jet which can be operated by a DC pump run by PV panels.

$>$ Chavan et. al. (2015): developed a prototype solar-powered agricultural pesticide sprayer using a 20W PV module and a brushless DC motor (12 V, 2.2 A).

$>$ Shivarajkumar A. and Parameswaramurthy D.: developed a wheel driven sprayer. The wheel operated pesticide spray equipment consists of a reciprocating pump to pressurize the liquid and power the reciprocating action of the pump. It is a portable device and does not require fuel for its operation; the main drawback of this equipment is that it cannot move in the land where the crops are already grown to a certain height and it is also difficult to carry on clay land.

$>$ Dr. R. N. Panchal Sir, Mr. Nikhil Deshmukh, Miss. PoonamShahapure, Miss. MrunaliniPatil, Miss.AshwiniKengale. Design a Monowheel Operated Pesticide Spraying Machine. They develop effective spraying and introduce new machines and techniques for the improvement and advancement of living standards of human beings.

S.Charvani, K.Sowmya, M.Malathi, P.Rajani, K.Saibaba. Design and Fabrication of a Solar Sprayer to studied and understand the mechanism for the spraying process. Mathematical models were developed after adopting suitable assumptions for calculation of the power of the motor required for spraying a known quantity of fluid. The parts required for the system were selected by solving for known input 
values and considering their availability in the market. The system was fabricated and arrangements were made on the system to make it portable and to allow the users to carry it on their back while in operation. The system was fabricated according to the design parameters and field-tested according to the standard test conditions (Krishna M.B, 2017).

Shailesh Malone, ShubhamKathwate, Pratik Kolhe, Rodney Jacob, NishatIngole, Rupesh D. Khorgade: Design and Development a Multipurpose Pesticides Spraying Machine that will enhance the productivity and increase the farmer's income and carries a multi-nozzle pesticides sprayer pump which will perform spraying at the maximum rate in minimum time. Constant flow valves are applied at the nozzle to have uniform nozzle pressure (Krishna M.B, 2017).

Mane Deshmukh Vijay, BhoirNilesh, GhadeTushar: Design and fabrication of an agriculture weeder as agricultural equipment useful for a farmer. This equipment is known as the weeder cycle. It has a weeder rotor adjustment cycle using inverter software to remove multiple kinds of grass between two rows in less time. Therefore fewer workers are required to remove grass (Krishna M.B, 2017).

$>$ Prof. N. R. Jadhao, ChinmayKadam, HaiderGazge, Rahul Dhania, and Nikhil Kalpund: Develop an Agricultural Sprayer Vehicle with Router Weeder and Seed Sower; the machine is beneficial to the farmer for spraying and weeding operation along with the seed sowing application. The multifunction device is handy and is used in different stages of farming as per requirement (Krishna M.B, 2017).

\section{MATERIALS AND METHODS}

\subsection{Materials and Specification}

\begin{tabular}{|c|c|c|c|c|c|}
\hline $\mathbf{S} / \mathbf{N}$ & MATERIAL & SPECIFICATION & DIMENSION & QTY & $\begin{array}{c}\text { COST } \\
(\mathbf{N})\end{array}$ \\
\hline 1. & Solar Panel & $50 \mathrm{~W}, 17.9 \mathrm{~V} \& 3 \mathrm{~A}$ & $74 \times 42.5 \times 3.5 \mathrm{~cm}$ & 1 & 12000 \\
\hline 2. & Charge controller & $12 \mathrm{~V} \& 20 \mathrm{~A}$ & - & 1 & 6500 \\
\hline 3. & D.C Battery & $12 \mathrm{~V} \& 12 \mathrm{Ah}$ & $15 \times 10 \times 10 \mathrm{~cm}$ & 1 & 9000 \\
\hline 4. & $\begin{array}{l}\text { Mini DC } \\
\text { reciprocating } \\
\text { cycle Motor }\end{array}$ & $\begin{array}{l}12 \mathrm{~V}, 0.13 \mathrm{~A}, 5 \mathrm{~W} \\
\& 600 \mathrm{rpm}\end{array}$ & $\begin{array}{l}12-20 \mathrm{~mm} \text { stroke and } \\
6-14 \mathrm{~mm} \text { output shaft }\end{array}$ & 1 & 12600 \\
\hline 5. & $\begin{array}{c}\text { Priming } \\
\text { Diaphragm Pump }\end{array}$ & $\begin{array}{l}12 \mathrm{~V}, 4.8 \text { bar, } 6 \mathrm{~W}-10 \mathrm{~W} \\
0.5-0.7 \mathrm{~A} \& 1.5-2 \mathrm{lits} / \mathrm{min}\end{array}$ & $\begin{array}{c}2 \mathrm{~m} \text { suction, } 6 \mathrm{~mm} \\
\text { inner and } 9 \mathrm{~mm} \text { outer } \\
\text { diameter }\end{array}$ & 1 & 9000 \\
\hline 6. & Tank & PVC Material & 20 lits & 1 & 8500 \\
\hline 7. & Connecting pipe & PVC Material & $\begin{array}{c}\text { Do }=12 \mathrm{~mm} \& \mathrm{~L}= \\
9.1 \mathrm{~m}\end{array}$ & 1 & 2000 \\
\hline 8. & $\begin{array}{l}\text { Multiple hollow } \\
\text { Nozzle }\end{array}$ & $\begin{array}{l}\text { Electric flexible mist } \\
\text { high-pressure nozzle }\end{array}$ & $\mathrm{Do}=0.75 \mathrm{~mm}$ & 1 & 3000 \\
\hline $\begin{array}{c}9 . \\
10 . \\
11 .\end{array}$ & $\begin{array}{l}\text { Square pipe } \\
\text { Angle iron } \\
\text { Bolt and Nut }\end{array}$ & $\begin{array}{c}1 \text { inch } \\
1 \frac{1}{2} \text { inch } \\
3 / 4 \text { inch } \\
25 \mathrm{~mm} \text { X } 25 \mathrm{~mm} \\
\text { Hexagonal }\end{array}$ & $\begin{array}{c}\text { Lengths } \\
1 / 2 \text { Length } \\
3 / 4 \text { Length } \\
1 / 4 \text { length } \\
10 \mathrm{~mm} \text { and } 14 \mathrm{~mm}\end{array}$ & $\begin{array}{c}3 \\
1 / 2 \\
1 / 2 \\
1 / 4 \\
16\end{array}$ & $\begin{array}{c}3000 \\
1500 \\
1000 \\
500 \\
500 \\
\end{array}$ \\
\hline 12. & Wheel & 400mm wheelbarrow tire & 1 & 1 & 2000 \\
\hline
\end{tabular}


Design, Fabrication, and Testing of a Movable Solar Operated Sprayer for Farming Operation

\begin{tabular}{|c|c|c|c|c|c|}
\hline 13. & $\begin{array}{c}\text { Solar bulb and } \\
\text { Charging kit }\end{array}$ & $5 \mathrm{~W}$ & 2 & 2 & 3000 \\
\hline 14. & Connecting wire & $4 \mathrm{~mm}$ & 6 yards & 350 & 2100 \\
\hline 15. & Switch & 2 gang & - & - & 400 \\
\hline 16. & $\begin{array}{c}\text { Purchase of } \\
\text { Fabrication } \\
\text { Materials }\end{array}$ & $\begin{array}{c}\text { cutting, welding, } \\
\text { grinding, painting \& } \\
\text { assembly }\end{array}$ & - & - & 15000 \\
\hline 17. & Transportation & - & - & - & 10000 \\
\hline 18. & Miscellaneous & $\begin{array}{c}\text { AutoCAD drawing, } \\
\text { Typing work, and others }\end{array}$ & - & - & 14600 \\
\hline & TOTAL & \multicolumn{2}{|c}{} & & 116,200 \\
\hline
\end{tabular}

\subsection{Methods}

\subsubsection{Design consideration}

> The total weight of the machine should be such that an operator can move it comfortably whenever it is required without any discomfort affecting his performance and health.

$>$ It should have DC power backup for not less than 4hours of operation.

$>$ The setup should be sturdy with ease of operation and controls along with low repair and maintenance costs.

> It should meet the technical, functional, operational, and structural requirements for quality spraying of pesticides and economically viable (Vinay S., 2016).

To avoid clogging, a mesh filter will be placed before the nozzle in the nozzle head to prevent clogging (Vinay S., 2016).

\subsubsection{Design calculation}

\subsubsection{The time required to charge the battery}

Battery rating $=12 \mathrm{AH} 12 \mathrm{~V}$

Current produced by the solar panel $(\mathrm{I})=\frac{\text { Maximum Power }(\mathrm{P})}{\operatorname{Voltage} \text { rating }(\mathrm{V})}=\frac{50}{12}=4.17 \mathrm{~A}$

Theoretical charging time $(\mathrm{T})=\frac{\text { Rating of battery }}{\text { Total current consumed }}=\frac{12}{4.17}=2.88 \mathrm{hrs}$

\subsubsection{Backup sprayer Time}

Reciprocating cycle mini gear motor $=12 \mathrm{~V} \& 0.13 \mathrm{~A}$ and Diaphragm pump $-12 \mathrm{~V} \& 0.7 \mathrm{~A}$

Backup sprayer Time $=\frac{\text { Power stored in battery }(\boldsymbol{w}-\boldsymbol{h r})}{\text { Power consumed }(\boldsymbol{w})}$

$$
\text { Backup sprayer time }=\frac{12 \times 12}{12 \times 0.13+12 \times 0.7}=\frac{144}{1.56+8.4}=\frac{144}{9.96}=14.5 \mathrm{hrs}
$$

\subsubsection{Power Conversion Efficiency of the Solar Panel}

Solar power conversion efficiency can be calculated as follows;

$$
\text { Power Conversion efficiency }(\eta)=\frac{\text { output power }}{\text { input power }}=\frac{p_{\text {out }}}{P_{\text {in }}}
$$


Issa, W.A, Abdulmumuni, B, Azeez, R.O, Okpara I.N, Fanifosi, J.O and Ologunye O.B

$\%$ P.C.E $=\frac{\text { Open circuit voltage } \times \text { Short circuit current }}{\text { incident solar radiation } \times \text { Area of the solar cell }}=\frac{64.2}{314.5} \times 100 \%=20.4 \%$

\section{RESULT AND DISCUSSION}

The results below where obtain after carrying out a test on the project as follows;

$>$ The system was placed in sunlight for $3 \mathrm{hrs}$ to charge from $12.4 \mathrm{~V}$ to $14.4 \mathrm{~V}$

$>$ Tested on tomatoes, maize, and open field in the farmland

$>$ The time required to charge the battery, time required to spray one (1) acre of land, flow rate and application rate was determined by using measuring bowl, stop watch, and grid

\subsection{Results}

Table 6.1: Experimental setup to plot the characteristics of battery voltage and fluid discharge to time

\begin{tabular}{|c|c|c|c|c|}
\hline $\begin{array}{c}\text { Battery } \\
\text { voltage } \\
\left(\mathbf{V}_{\mathbf{1}}\right)\end{array}$ & $\begin{array}{c}\text { Battery voltage } \\
\left(\mathbf{V}_{\mathbf{2}}\right)\end{array}$ & $\begin{array}{c}\text { Volume } \\
(\mathbf{l i t e r})\end{array}$ & $\begin{array}{c}\text { Time } \\
(\mathbf{m i n})\end{array}$ & $\begin{array}{c}\text { Discharge } \\
(\mathbf{Q})(\mathbf{l i t} / \mathbf{m i n})\end{array}$ \\
\hline 13.60 & 13.50 & 1.00 & 1.27 & 0.79 \\
\hline 13.50 & 13.40 & 2.00 & 2.52 & 0.79 \\
\hline 13.40 & 13.30 & 3.00 & 3.77 & 0.80 \\
\hline 13.30 & 13.20 & 4.00 & 4.95 & 0.81 \\
\hline 13.20 & 13.10 & 5.00 & 6.00 & 0.83 \\
\hline
\end{tabular}

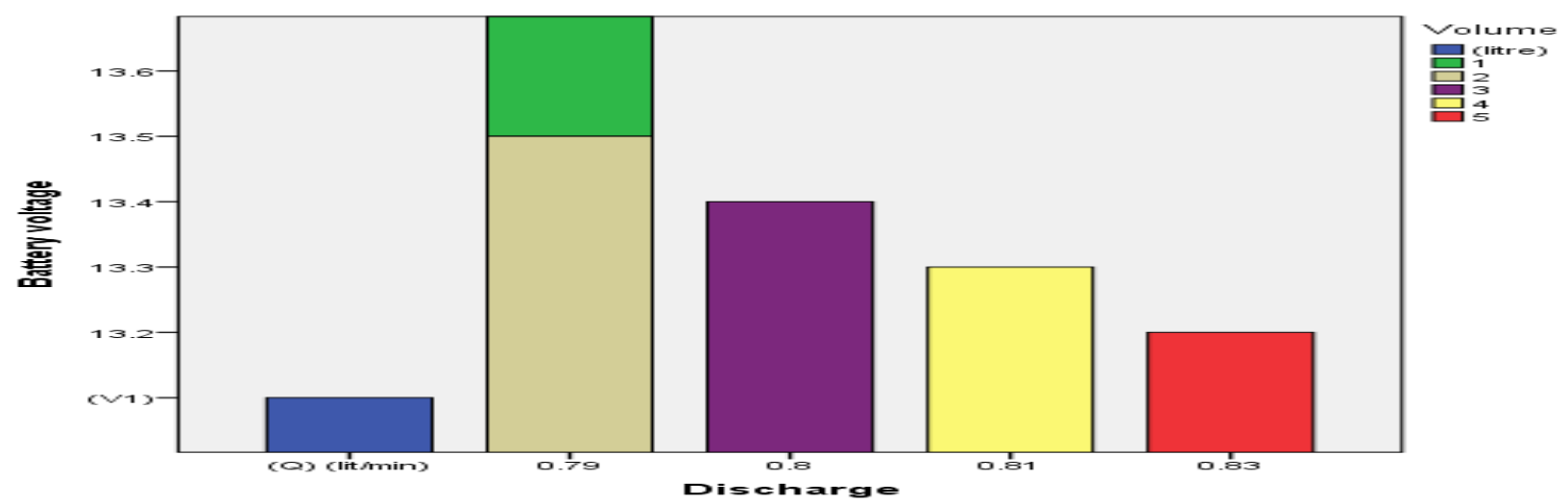

Figure 5.1: Characteristics of battery voltage and fluid discharge to time

\subsubsection{Time required operating the sprayer while being charged and discharged simultaneously}

The fully charged battery at $14.4 \mathrm{~V}$ can last for eight (8) hours before dropping to $12.74 \mathrm{~V}$ when used to spray fluid, charge phone and light up 5W energy bulb concurrently.

\subsubsection{Application rate}

Application rate $\left(\frac{\mathrm{L}}{\mathrm{m}^{2}}\right)=\frac{\text { Volume collected }(\mathrm{L}) \times \text { Time }(\mathrm{min})}{\text { Time }(\min ) \times \text { Area of test plot }\left(\mathrm{m}^{2}\right)}$

$$
\text { A. } R=\frac{1 \times 1.27}{1.27 \times 25}=\frac{1.27}{31.75}=0.04 \mathrm{~L} / \mathrm{m}^{2}
$$


Design, Fabrication, and Testing of a Movable Solar Operated Sprayer for Farming Operation

\subsubsection{Determination of Flow Rate}

$$
\begin{aligned}
& \text { Flow rate }(Q) \text { in } \frac{\text { Lit }}{\text { Sec }}=\frac{\text { Volume of liquid collected }(\text { Lit })}{\text { Time }(\text { min })} \\
& \qquad F . R=\frac{1}{1.27}=0.79 \mathrm{~L} / \mathrm{min}
\end{aligned}
$$

\subsubsection{Pump Efficiency}

$$
\begin{aligned}
\text { P.E }(\eta)= & \frac{\text { Power needed to deliver water }}{\text { Power supplied by the battery }} \\
& \text { P.E }(\eta)=\frac{12 \times 0.7}{12 \times 3}=\frac{8.4}{36} \times 100 \%=23.33 \%
\end{aligned}
$$

5.1.5. Pressure discharge relationship of the pump

$$
\begin{aligned}
& \text { Pump capacity }=\frac{\text { Hydraulic Power }}{\text { Efficiency of the pump }} \\
& \begin{aligned}
\text { P. C }=\frac{\rho g h Q}{\eta}= & \frac{1000 \times 9.81 \times 8.7 \times 0.013}{0.2333}=\frac{1109.511}{0.2333}=4755.727 \mathrm{~W} \\
& =4.756 \mathrm{~kW}
\end{aligned}
\end{aligned}
$$

\subsection{Discussions}

The system can work for 8 hours with a voltage drop from $14.4 \mathrm{~V}$ to $12.74 \mathrm{~V}$

$>$ The fluid discharge is $0.79 \mathrm{~L} / \mathrm{min}$

$>$ Can spray 162 liters of pesticide or herbicide on 1 acre of land in $2 \mathrm{hrs} 13 \mathrm{mins}$.

$>$ Fine droplets of atomized particles were obtained.

\section{CONCLUSION AND RECOMMENDATION}

\subsection{Conclusion}

$>$ The result shows that the system is efficient, portable and provides at least 8 hours of operation daily

$>$ The system will enhance the working capacity of the farmer by reducing the time and fatigue

The system can spray between 600 - 650 liters of chemicals on 3 to 4 acres of land

$>$ The system is incorporated with an energy bulb and charging kit to light up the farmyard and for the operator to charge his/her phone

The initial cost of the system is a little higher but does not require running cost

\subsection{Recommendations}

$>$ Incorporating fiber reinforced plastic (FRP) to reduce the weight between $2 \mathrm{~kg}$ to $3 \mathrm{~kg}$

$>$ The system can be automated using microcontroller

$>$ Incorporating the concentric collector to increase charging efficiency

$>$ Energy can be saved using PWM Scheme to drive the pump. 
Issa, W.A, Abdulmumuni, B, Azeez, R.O, Okpara I.N, Fanifosi, J.O and Ologunye O.B

\section{REFERNCES}

[1] Ahalya M., M. A. (2017). Solar Powered Semi-Automatic Pesticide Sprayer applicable in Vineyards. Seventh Sense Research Group International Journal of Electronics and Communication Engineering, 4, 54-57.

[2] Arunkumar M., K. N. (2015). Design and Fabrication of Portable Solar. India: Mechanical Engineering Department, University B.D.T College of Engineering.

[3] Chavan R., H. A. (2015). Design and construction of solar-powered agricultural pesticide sprayer. (4, Ed.) International Journal of Innovations \& Advancement in Computer Science, 4, 145-150.

[4] Joshua R., V. (2010). Solar Sprayer - An Agriculture Implement 2. International Journal of Sustainable Agriculture, 1, 16-19.

[5] Khan, Z. (2014). Unique solar operated spray jet. IOSR Journal of Mechanical and Civil Engineering (IOSR-JMCE), 43-46.

[6] Krishna M.B, R. K. (2017). Solar Pesticide Sprayer. International Journal of Latest Engineering Research and Applications, 2(2455-7137), 82-89.

[7] Pandurang L., V. P. (2015). Solar operated Pesticide Sprayer. International Journal of Advanced Research in Science and Engineering, 1-5.

[8] Rahul V.K, S. M. (2018). Fabrication of Wireless Operated Solar Pesticide Sprinkler. International Journal of Advanced Research in Science and Engineering, 4, 260-270.

[9] Rao V.V., M. S. (2013). International Journal of Scientific and Research Publications. (3, Ed.) Multiple power supplied fertilizer sprayer, 8, 1-10.

[10] Singh K., P. D. (2018). Development of a Solar Powered Knapsack Sprayer. Journal of Pharmacognosy and Phytochemistry, 1269-1272.

[11] Varikuti V.R, S. M. (2013). Multiple Power Supplied Fertilizer Sprayer. International Journal of Science and Research Publications of Electrical and Electronic Engineering (PDACE), 1-5.

[12] Venkateswarlu M., K. M. (2016). Agricultural Solar Sprayer with Multi Applications. Journal of Mechanical and Civil Engineering, 2(2456-1479), 1-7.

[13] Vinay S., D. K. (2016). Design and development of Solar Photovoltaic based power sprayer for Agricultural use. Article in Annals of arid Zone 55 (182), pp. 51-57. 


\section{APPENDIX A ASSEMBLY AND EXPLODED DIAGRAM OF A MOVABLE SOLAR OPERATED SPRAYER FOR FARMING OPERATION}

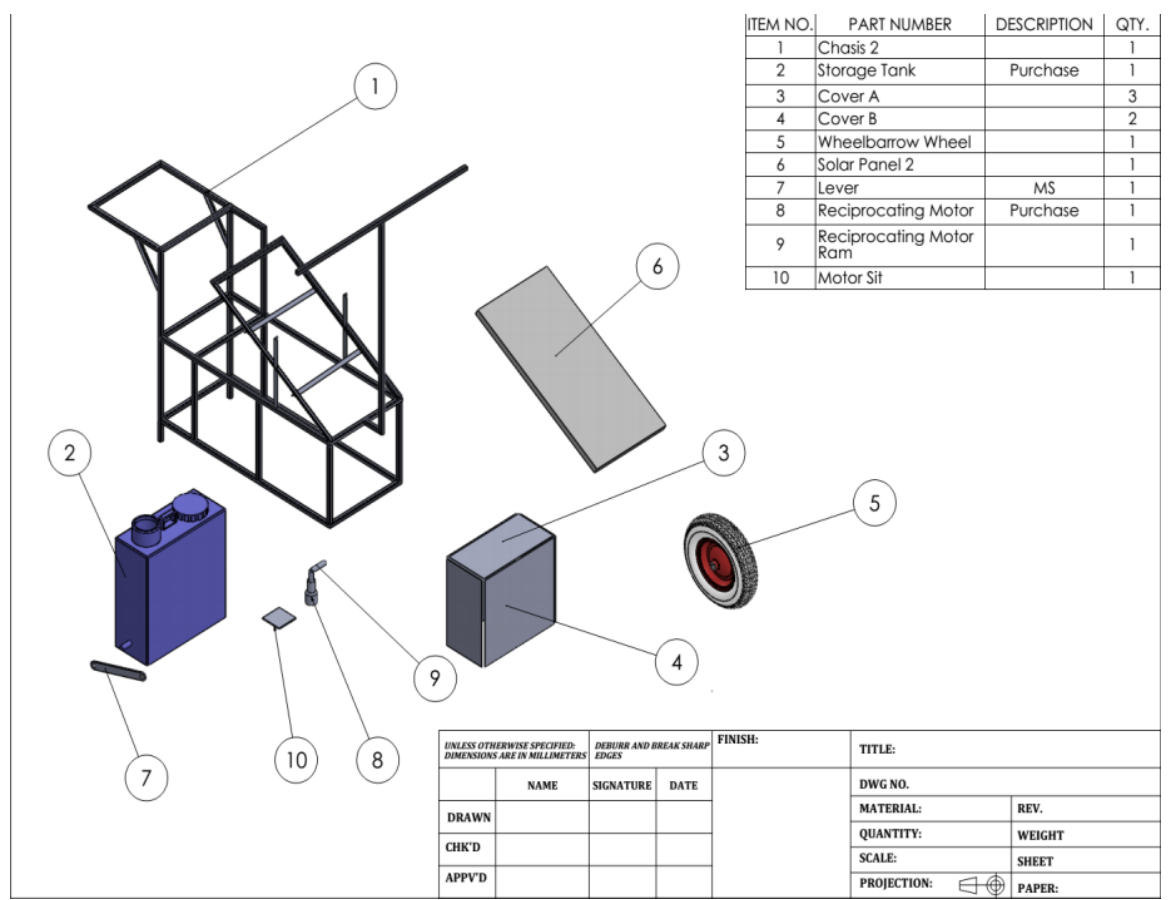

APPENDIX B: THE FABRICATED MOVABLE SOLAR OPERATED SPRAYER FOR FARMING OPERATION

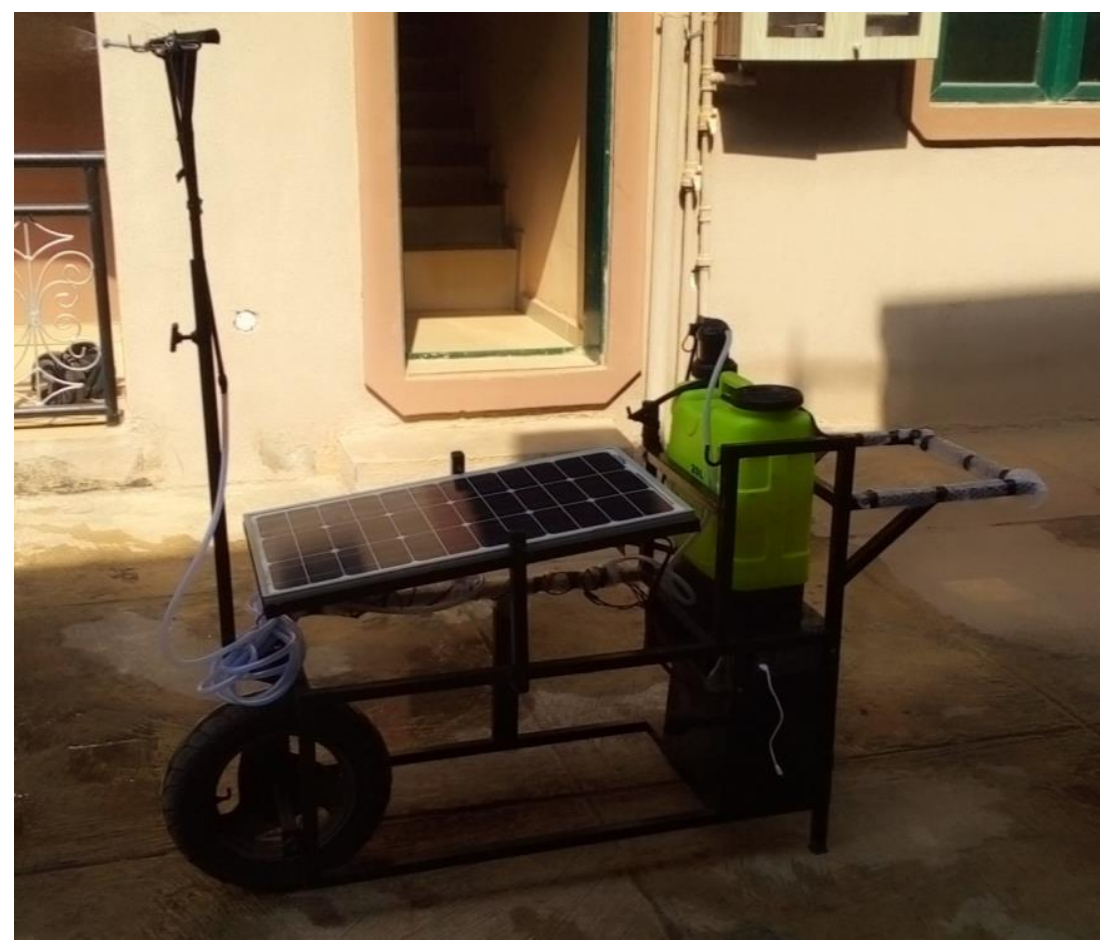

